\title{
Artigo
}

\section{Redemocratização e partidos políticos no Brasil e no Chile: incentivos institucionais, sistema partidário e processo decisório ${ }^{1}$}

\author{
Redemocratization and political parties in Brazil and \\ Chile: institutional incentives, party system and \\ decision-making process
}

\author{
Bruno Pasquarelli \\ Professor, Universidade do Sagrado Coração (USC), \\ Bauru, SP, Brasil \\ brunopasqua@gmail.com
}

\begin{abstract}
Resumo: $O$ estudo examina o desenvolvimento dos processos políticos do contexto de redemocratização no Brasil e no Chile, considerando a importância dos partidos políticos de ambos os países como variável explicativa para a configuração do ambiente político-institucional. Para tanto, será elaborada uma investigação exploratória e comparativa acerca da evolução do sistema político dos dois países a partir das variáveis explicativas relacionadas ao sistema político, ao sistema partidário e às relações entre Poder Executivo e Poder Legislativo, demonstrando o tipo de competição partidária e de institucionalização, assim como a importância da formação de coalizões como variável central ao processo de formulação de políticas públicas.
\end{abstract}

Palavras-chave: Coalizão; Partidos políticos; Presidencialismo; Processo Decisório.

\footnotetext{
Abstract: The study examines the development of political processes in the context of redemocratization in Brazil and Chile, considering the importance of political parties of both countries as an explanatory variable for the configuration of the political-institutional environment.

1 Artigo extraído da tese de doutorado intitulada "Política externa, partidos políticos e relações executivo/legislativo nas democracias presidencialistas do Brasil e do Chile", defendida no ano de 2015, com o auxílio da FAPESP (Fundação de amparo à pesquisa do Estado de São Paulo) e Capes (Coordenação de aperfeiçoamento de pessoal de nível superior), sob a orientação da Profa. Dra. Maria do Socorro Sousa Braga.
} 
To do so, an exploratory and comparative research will be carried out on the evolution of the political system of the two countries based on the explanatory variables related to the political system, the party system and the relations between Executive Power and Legislative Power, demonstrating the type of part-institutionalization, as well as the importance of the formation of coalitions as a central variable in the process of formulating public policies.

Keywords: Coalition; Political parties; Presidentialism; Decision-making process.

\section{Introdução}

Este estudo examina as democracias presidencialistas do Brasil e do Chile ao longo do atual período democrático com o objetivo de demonstrar como os regimes e sistemas políticos anteriores moldaram e influenciaram a configuração político-institucional, o sistema partidário e as relações entre Executivo e Legislativo de cada país analisado, acarretando configurações diferentes no processo de tomada de decisão das mais variadas políticas públicas.

Sendo assim, em primeiro lugar, o estudo faz uma reconstituição do sistema político-partidário do Brasil e do Chile ao longo dos anos e após a redemocratização ocorrida em meados da década de 1980, verificando se a mudança no regime político alterou ou manteve os alicerces políticos básicos do período democrático, dentre eles, o sistema partidário, o sistema eleitoral, os partidos políticos, e as relações Executivo/Legislativo.

O Chile manteve muitas das facetas do regime militar, os chamados enclaves autoritários, tais como a Constituição de 1980, o que garantiu a continuidade dos principais partidos políticos anteriores ao regime militar, com divisão mais acentuada entre direita e esquerda e alto grau de polarização entre situação e oposição e de estabilidade interna nas coalizões de governo, o maior consenso em torno do processo decisório. A hipótese a ser examinada, por conseguinte, é que a configuração institucional do regime militar chileno propiciou a formatação de um sistema político com proeminência do Poder Executivo, mas com a presença de partidos políticos que estavam presentes no período pré-autoritarismo, resultando em um sistema partidário fortemente institucionalizado e com legendas partidárias com preferências mais coesas e com centralidade do fator ideológico, delimitando a configuração político-partidária e aumentando o grau de consenso em torno das políticas públicas.

No Brasil, por sua vez, a engenharia institucional do novo período democrático permitiu o surgimento de novos partidos políticos, substituindo o bipartidarismo do 
regime militar; mas, mesmo com o pluripartidarismo em evidência, apenas PT e PSDB se tornaram as principais forças para concorrer para a Presidência da República, enquanto que os demais partidos concentraram-se para obtenção de outros cargos executivos e legislativos. Com isso, tais partidos procuraram construir coalizões amplas em busca da governabilidade no processo decisório, desconsiderando, em alguns casos, o fator ideológico para busca de apoio congressual.

Por conseguinte, o regime militar, nos dois casos, procurou instituir o pluripartidarismo como forma de manter seu poder. No entanto o que se viu foi cada vez mais uma divisão entre centro-esquerda e centro-direita, com a formação de duas coalizões estáveis no Chile e do fortalecimento de PT e PSDB no Brasil, que formaram coalizões com viés mais amplo e heterogêneo.

A seguir, o estudo analisará o contexto de redemocratização e de reorganização dos sistemas pluripartidários em cada país, destacando suas especificidades e seus principais atores, assim como a dinâmica de relacionamento entre Poder Executivo e Poder Legislativo e de formação de coalizões. Isso porque, com o retorno da democracia, tanto Chile quanto Brasil tiveram seus sistemas presidencialistas moldados a partir de instituições previamente existentes, nos moldes dos regimes autoritários. Então, o sistema de partidos, a presença de um Poder Executivo forte e centralizado, e a dinâmica de formação de coalizões são variáveis contextuais imprescindíveis para se compreender a configuração do processo de tomada de decisão das políticas públicas em geral.

\section{Regime militar, política partidária e redemocratização no Brasil}

O regime militar brasileiro, que se iniciou em 1964 e perdurou até 1985 (com a eleição de Tancredo Neves), teve fases distintas. A primeira fase, que vai de 1964 até 1974, pode ser vista como o início da atividade repressiva, sendo que em 1968, houve a supressão de direitos políticos. Já a segunda fase teve início em 1974, com Ernesto Geisel na presidência, iniciando-se diversas tentativas de liberalização do sistema.

Nos primórdios do regime militar, o governo Castelo Branco manteve os partidos políticos. No entanto, em 1965, após ser derrotado nas eleições para os governos de estado, as legendas foram extintas. Já em 1966, os militares aboliram os partidos existentes até então e instituíram o bipartidarismo sem alternância de poder, criando 
T\&P Redemocratização e partidos políticos no Brasil e no Chile: incentivos institucionais, sistema partidário e processo decisório

a Arena (Aliança Renovadora Nacional) e do MDB (Movimento Democrático Brasileiro). À Arena caberia sempre a posição de sustentar o novo regime, aprovando grande parte dos projetos de cunho repressivo, e ao MDB, de efetuar uma oposição dentro dos limites estabelecidos pelos governantes, vivendo um dilema: manter-se em funcionamento, com poucas condições de uma forte oposição, ou dissolver-se (CARVALHO, 2008).

Em 1967, com a promulgação da nova Constituição, ratificou-se o bipartidarismo, e estabeleceu-se que as eleições para os cargos executivos estaduais e municipais seriam indiretas, assim como as eleições para a Presidência da República. Com a instauração do Ato Institucional n. 5, o Congresso foi fechado, e diversos mandatos políticos foram cassados. Como resultado, os partidos eram controlados pelo governo. De acordo com Kinzo (2001), tratava-se de um regime tipicamente militar; no entanto, havia arena de disputa pelo poder político, pois foi mantido o funcionamento de alguns mecanismos de democracia representativa, em um arranjo que combinava traços autoritários com democráticos.

Em 15 de março de 1974, o presidente Médici foi substituído pelo general Ernesto Geisel. Em seus pronunciamentos, Geisel utilizava a expressão distensão lenta, segura e gradual para retornar à democracia. Ou seja: o regime militar promoveria a abertura política, mas sem deixar o processo escapar do seu controle. No entanto, o modo de condução do processo de liberalização foi influenciado por vários fatores (KINZO, 1990). O primeiro fator foram as eleições. Em 1974, houve um surpreendente desempenho eleitoral do partido de oposição, o MDB - que foi eleito para 16 das 22 cadeiras do Senado Federal. O segundo fator era a instituição militar e seus diversos conflitos internos. Já o terceiro fator estava ligado ao agravamento da situação econômica do país, com evidências de que o milagre econômico estava se esgotando.

Sendo assim, a partir do governo Geisel, com a diminuição do crescimento da economia brasileira e com as crises internas entre os setores militares e civis, o esgotamento do modelo militar começou a aparecer². A oposição, então, começou a mobilizar a sociedade para pressionar o governo. Passou-se a exigir anistia ampla,

2 Tais fatores não impediram que o governo militar procurasse conter o avanço visível da oposição que vinha ocorrendo desde 1974. Em 1976, por exemplo, limitou a propaganda eleitoral e os debates foram proibidos. Já em 1977, decretou um conjunto de medidas repressivas conhecido como Pacote de Abril, onde o Congresso foi fechado, o mandato do presidente da República aumentou para seis anos, manteve-se a eleição indireta para governadores por colégios eleitorais estaduais manipulados para favorecer a Arena, e estabeleceu-se que um terço dos senadores passaria a ser eleito de modo indireto. Com isso, nas eleições legislativas de 1978, a Arena conseguiu recuperar muitas cadeiras que havia perdido nas eleições de 1974 . 
geral e irrestrita a todos os presos políticos, exilados e cassados. Diante da crescente pressão da sociedade civil, o Congresso aprovou proposta do governo, pelo qual o Al-5 ficava revogado a partir de primeiro de janeiro de 1979. Geisel, então, escolheu como seu sucessor na presidência da República o general João Baptista Figueiredo, que tinha o compromisso de aprofundar o processo de abertura política. Sendo assim, em 28 de agosto de 1979, o governo sancionou a Lei da Anistia. No mesmo ano, o bipartidarismo foi extinto através de lei aprovada pelo Congresso, sendo que o pluripartidarismo era visto como uma estratégia do próprio governo para dividir a manter a oposição sob controle, pois os partidos oposicionistas se tornariam menos unidos e coesos (KINZO, 2001).

Então, o atual sistema partidário brasileiro se originou em 1982, sendo vinculado com fim do regime militar e com o processo de reconstrução da democracia representativa no país. Com a extinção do bipartidarismo, em 1979, a nova configuração partidária compreendia cinco legendas: dois partidos sucessores - da Arena, o PDS, e do MDB, o PMDB; um novo partido de centro, o PP (formado por moderados do ex-MDB, liderados pelo senador Tancredo Neves, e dissidentes liberais da Arena, liderados pelo deputado Magalhães Pinto)3; o ressurgimento de um partido trabalhista nos moldes do antigo PTB, liderado pelo ex-governador Leonel Brizola e pela ex-deputada Ivete Vargas 4 ; e a possibilidade de surgimento de um partido baseado no novo sindicalismo emergente nas regiões Sul e Sudeste - o PT, liderado por Luis Inácio Lula da Silva. Ademais, é importante salientar que o realinhamento partidário pós-1979 teve como ponto de referência a Arena e o MDB, e não os partidos do regime de 1946 (KINZO, 1990, p. 39) - diferentemente, como veremos a seguir, do caso chileno. Então, a nova estrutura partidária do presidencialismo brasileiro assumiu um formato divergente do período militar, com o advento do pluripartidarismo em detrimento do bipartidarismo.

Em 1982, o primeiro pleito contou com cinco partidos (PMDB, PDS, PDT, PTB e PT), e incluiu a escolha para o governo dos estados e suas respectivas Assembleias Legislativas, para o Congresso Nacional, e para as prefeituras e Câmaras Municipais, de maneira que o regime militar perdeu sua maioria absoluta na Câmara dos Deputados. Ademais, o

3 Nas eleições de 1982, o governo Figueiredo tentou garantir a hegemonia do PDS através do voto vinculado e da proibição de coligações. Com isso, o PP se sentiu inviabilizado e se reincorporou ao PMDB. Então, O PP, em consequência dos obstáculos criados pelo chamado "Pacote Eleitoral" de novembro de 1981, resolveu incorporar-se ao PMDB, visando aumentar suas chances eleitorais.

4 Porém, pouco depois o PTB se dividiu, fazendo com que Brizola criasse um novo partido, o PDT. 
T\&P Redemocratização e partidos políticos no Brasil e no Chile: incentivos institucionais, sistema partidário e processo decisório

PMDB ganhou as eleições estaduais em São Paulo, Minas Gerais, Paraná, Acre e Pará; já o PDT venceu no Rio de Janeiro, com Leonel Brizola. O Brasil, então, ficou dividido politicamente, sendo que o PMDB se elegeu onde havia vida política mais intensa. Com isso, os alicerces excludentes do regime militar foram abalados por um vigoroso processo de democratização política (KINZO, 1990).

Com a promulgação da Emenda Constitucional n²5, em 1985, o processo de formação de novas organizações partidárias foi flexibilizado e houve a fusão de novos partidos, estabelecendo a liberdade total de organização partidária, e impulsionando a reorganização de partidos comunistas 5 , do Partido Socialista Brasileiro (PSB), e de várias outras legendas pequenas, oriundas de grupos do PMDB e do PDS. Da direita, egressos do PDS, foram criados o PDC e o PL. Assim, o sistema partidário expandiu-se de 5 para 11 partidos, e o PMDB tornou-se dominante (KINZO, 1990; NICOLAU, 2004).

Em 1985, derrotada a campanha das Diretas-Já, a escolha do novo presidente ocorreu conforme os ditames da ditadura, de forma indireta, pelo Colégio Eleitoral - formado pelos integrantes do Congresso Nacional (deputados e senadores) e por representantes das Assembléias Legislativas estaduais - mantendo o controle dos militares sobre a sucessão presidencial. Tendo em vista a sucessão presidencial marcada a cargo do Colégio Eleitoral para 15 de janeiro de 1985, promoveu-se uma cisão no PDS em torno da escolha do seu candidato para a eleição indireta. Uma facção dentro do PDS, liderada por Aureliano Chaves, Marco Maciel e José Sarney, preconizava a realização de uma eleição prévia interna no partido para determinar o seu candidato à Presidência da República. Já o grupo majoritário governista decidiu manter o mecanismo tradicional de articulações informais numa convenção nacional do partido. O grupo dissidente, denominado Frente Liberal, selou a Aliança Democrática com o PMDB e articulou a chapa com Tancredo Neves para presidente e José Sarney para vice-; quanto ao PDS, sua convenção nacional escolheu o ex-governador Paulo Maluf para presidente e o deputado Flávio Marcílio para vice. Com isso, a chapa da Aliança Democrática conseguiu 113 votos dos dissidentes da Frente Liberal e ainda 55 votos dos que permaneceram no PDS, vencendo, assim, a chapa Maluf-Marcílio por uma margem de 300 votos.

5 Da esquerda, saíram da clandestinidade os dois partidos até então enrustidos no PMDB - o PCB e o PCdoB - e também o PSB. 
Com a eleição de Tancredo Neves, em 1985, o pacto conservador fora preservado, pois mesmo fora do poder, o viés militar continuou por trás da presidência. Neves adotou a composição política que garantiu ao capital nacional e internacional uma transição sem turbulências. Ou seja: a ditadura não seria totalmente desmantelada politicamente, servindo de guia para a democratização.

Por conseguinte, o impacto do autoritarismo sob o sistema partidário foi marcante. Por um lado, legitimou o processo eleitoral como a principal via de resistência à ditadura. Porém, ao mesmo tempo, reforçou a adesão partidária e o aprofundamento da relação de dependência dos partidos em relação ao Estado com a extensão do processo decisório burocrático-centralizador (CARDOSO, 1988). O regime autoritário brasileiro, então, teve papel crucial na formação dos partidos políticos - que não se originaram do Parlamento e não são movidos por uma concepção global de mundo. Convém destacar que o processo de abertura política teve duas estratégias básicas: a continuidade, que permitiu que a elite política se mantivesse no poder, e o conservadorismo, com ausência de um projeto articulado e consensual pelas forças de oposição ao autoritarismo, confinando-as a um espaço limitado pelos alicerces institucionais do regime precedente (SOUZA, 1988). A partir dessa constatação, o processo político-partidário de meados da década de 1980 é caracterizado pela existência de um vasto centro, o qual Souza (1988) denomina de centrismo invertebrado. Ou seja: há a presença do velho regime no interior dos dois partidos que inicialmente sustentaram a Nova República e o comando dos ministérios (o PMDB e o PDS), o que mostra o perfil conservador do processo democrático. Contudo, é preciso considerar que cada partido não é formado por uma unidade coesa, possuindo pensamentos e atitudes divergentes. O PMDB, por exemplo, acabou por implodir a tese do centésimo invertebrado quando uma ala mais à esquerda do partido fundou o PSDB.

De acordo com Souza (1988, p. 593, 600), os partidos políticos do período de 1985 a 1989 foram "[...] diversos dos anteriores, em suas siglas, na amplitude de suas bases, nos seus pontos programáticos e mesmo na militância de seus quadros". Porém, ainda eram extremamente frágeis na função governamental e decisória, e especialmente na representação de interesses da população, dependendo do acesso às benesses estatais. Com o papel central do Estado na política partidária, o clientelismo cresceu à medida que aumentava a incerteza dos resultados eleitorais; nesse sentido, a competição partidária, 
T\&P Redemocratização e partidos políticos no Brasil e no Chile: incentivos institucionais, sistema partidário e processo decisório

ainda incipiente, era baseada na disputa pelos recursos do Estado - que, por sua vez, dificultaram o fortalecimento inicial da democratização política.

Por conseguinte, o período de transição democrática foi caracterizado por um quadro de indefinição partidária acentuado que dificultou o desenvolvimento dos partidos no Brasil. Tal quadro, segundo Kinzo (1990), tem ligação com três fatores. Em primeiro lugar, devido ao peso excessivo da estrutura estatal no sistema político (SOUZA, 1990). Em segundo lugar, em razão da herança do autoritarismo, de maneira que a interferência do governo militar na estrutura partidária dificultou sua estabilidade. E, em terceiro lugar, a própria transição política, pois o caminho de liberalização dos militares brasileiros seguiu uma estratégia que limitava a capacidade das forças oposicionistas.

Já em 1988, com a consolidação do arranjo político-institucional após a promulgação da Constituição Federal, que manteve a estrutura federativa, a forma presidencial do sistema de governo e o Congresso Nacional bicameral, alguns políticos se desligaram do PMDB e fundaram o PSDB. E, no início dos anos 1990, mais de 30 partidos participavam do sistema político partidário do Brasil, embora um número bem menor competiu em todos os 15 pleitos realizados durante os 25 anos de competição partidária. A Nova República, então, estava inaugurada. Mas seria mesmo uma Nova República ou haveria a manutenção de algumas características do regime militar na democracia? Haveria inovação político-partidária ou manutenção da ordem antiga?

De acordo com Braga (2006), o sistema partidário inicial era caracterizado pela presença de partidos com perfis diferenciados que expressavam posições político-programáticas definidas no espectro ideológico, e eram dotados de recursos políticos e organizacionais desiguais. Assim, enquanto PDS e PMDB eram estruturados e dispunham da maioria dos recursos públicos, PTB, PDT e PT não se caracterizavam pela presença de bases organizacionais e de uma quantidade expressiva de parlamentares.

No entanto, o desgaste do PMDB ao longo do governo Sarney (1985-1990) propiciou as condições para mudanças na correlação de forças partidárias. E, no contexto de redemocratização, Luis Inácio Lula da Silva se candidatou para a presidência nas eleições de 1989, sendo o segundo candidato mais votado 6 . Com isso, o PT iniciou a conquista de uma posição hegemônica na esquerda do país.

\footnotetext{
6 Nas eleições de 1989, dois candidatos de partidos pequenos, Fernando Collor (PRN) e Lula (PT), foram para o segundo turno. Já os dois maiores partidos, parceiros na Aliança Democrática - o PMDB e o PFL -, ficaram reduzidos à sétima e nona posições na corrida presidencial: Ulysses Guimarães, com 4,74\%, e Aureliano Chaves, com 0,89\% dos votos válidos. No segundo turno, realizado em 17 de dezembro, Collor se elegeu com 49,94\% dos votos, contra os 44,21\% de Lula.
} 
Após as eleições de 1995, que alçaram o PSDB de Fernando Henrique Cardoso para a presidência do país, a dinâmica do sistema partidário brasileiro polarizou-se em torno de duas grandes coligações de partidos, que se mantiveram em lados opostos: uma de centro-direita, liderada pelo PSDB e pelo PFL/DEM, e outra de centro-esquerda, controlada pelo PT. Enquanto a coligação de centro-direita venceu novamente as eleições de 1998, reelegendo Cardoso com 53,1\% dos votos válidos, a coligação de centro-esquerda, liderada por Lula da Silva, venceu os pleitos de 2002 e de 2006, ambos com 62\% dos votos da população no segundo turno, de 2010 e 2014, elegendo Dilma Rousseff (PT) por duas vezes consecutivas.

Ao observar a atuação dos partidos em eleições nacionais presidenciais, Braga (2010) constatou que PSDB e PT foram os principais partidos que arregimentaram votos, o que mostra uma dinâmica de bipartidarismo no âmbito federal. Isso porque ambos se configuraram "[...] como organizações políticas que agregam líderes e quadros políticos ao redor de um programa nacional. Além de programáticos são também partidos ideológicos, que defendem projetos políticos diversos para o país". (BRAGA, 2010, p. 63-64)7. No entanto, se observarmos apenas as disputas para o Congresso Nacional, o PMDB foi o partido mais competitivo até 1994. Após esse período, PSDB, PT e PFL/DEM equalizaram o poder eleitoral na competição proporcional. Sendo assim, o sistema brasileiro vem caminhando para uma estrutura de competição mais fechada, concentrada em duas forças partidárias (para cargos do Executivo nacional) e em torno de um maior número de partidos para o Poder Legislativo - denominada como uma estrutura de competição multipartidária moderada (BRAGA, 2010, p. 70). Portanto, tanto PT quanto PSDB vêm controlando os principais cargos eletivos do país, sendo que o primeiro tornou-se a principal força proveniente do campo da esquerda. Por conseguinte, apesar do regime militar procurar instituir um sistema partidário pluripartidário e com baixa tendência ideológica de esquerda, os últimos vinte e cinco anos de democracia evidenciaram o fortalecimento de um partido de centro-esquerda (PT) e um de centro-direita (PSDB), que passaram a polarizar as disputas para os principais cargos nacionais.

7 De acordo com Braga (2010, p. 64), o PMDB possui baixo rendimento nas eleições presidenciais porque não possui projeto político para o país, configurando-se como uma confederação de grupos políticos estaduais e onde prepondera a descentralização. 


\section{A evolução do sistema partidário chileno: sistema eleitoral e enclaves autoritários}

O Chile conta com uma extensa tradição democrática - ainda que nas décadas de 1920 e 1970 tenha vivido relevantes experiências autoritárias - com um sistema de partidos de caráter estável (SCULLY, 1995), estruturalmente alinhados em blocos ideológicos e com a presença de um Poder Executivo forte (SIAVELIS, 2000).

Porém, para entender o funcionamento do sistema partidário atual, é necessário compreender como o mesmo se desenvolveu ao longo de um amplo período situado no tempo. Desde o século XIX, a evolução do sistema partidário do país ocorreu em torno de três clivagens: religiosa, urbana e rural (SCULLY, 1995). Em meados do século XIX, a clivagem religiosa era predominante, sendo que o conflito entre partidos clericais e anti-clericais era fundador do panorama político-partidário do país. No período, havia três tendências políticas, com quatro partidos políticos distintos que formavam alianças entre si: o Partido Radical (anti-clerical), o Partido Liberal e o Partido Nacional (centro) e o Partido Conservador (clerical). Tanto os conservadores quanto os liberais se alternaram no poder até 1920, mas dependiam dos liberais e dos nacionais para construção de maiorias (SCULLY, 1995, p. 104).

Nas primeiras décadas do século XX, a emergência de novos atores ligados à classe trabalhadora urbana fez aumentar as demandas para a inclusão social. Foram criados, então, o Partido Democrático e o Partido Comunista, que passaram a atrair os votos dos trabalhadores e da nova classe média em ascensão; no entanto, após Arturo Alessandri (político populista com apoio dos democratas e dos radicais), vencer as eleições de 1920 e permanecer até o fim do seu mandato, em 1924, os militares tomaram o poder e fecharam o Congresso, reprimindo os partidos e exilando líderes partidários. Já em 1931, o coronel Carlos Ibañez foi deposto devido à crise econômica; e, em um período de intensa mobilização dos sindicatos e das organizações trabalhistas, as classes trabalhadoras urbanas deveriam ser incorporadas em partidos viáveis; surgia, então, o Partido Socialista (SCULLY, 1995, p. 109). Nesse sentido, o período passou a ser caracterizado pelo pluralismo, pois haviam 27 partidos; destes, 9 detinham representatividade congressual. Mas, apesar do pluralismo, um sistema tripartite ainda era visível por meio da clivagem de classe urbana, com partidos de esquerda (PC e PS), de centro (PR, mais flexível) e de direita (conservadores e liberais).

Já nas décadas de 1950, 1960, e 1970, a arena partidária classista se expandiu à medida que houve o aparecimento de novos atores. À esquerda, grupos ligados a Ibañez, e o recém- 
formado Partido Democrata Cristão (formado a partir da cisão entre nacionais e conservadores) passaram a construir fortalezas eleitorais nas áreas rurais, sendo que o controle oligárquico sobre o campesinato tornou-se o alicerce do sistema partidário (SCULLY, 1995, p. 112). No entanto, o PR ainda era a principal legenda, pois detinha capacidade de moldar alianças. E, com o predomínio dos radicais, os partidos ligados à classe trabalhadora fundaram a FRAP (Fronte de Ação Popular) e passaram a aceitar a hipótese de não cooperação com os partidos burgueses, apresentando suas próprias candidaturas e reforçando a rigidez e a polarização (SCULLY, 1995, p. 115). Ao mesmo tempo, após a eleição do caudilho Carlos Ibañez, em 1952, diversos partidos pequenos ascenderam ao poder, assinalando a terceira reorganização do sistema partidário, pois houve elevada fragmentação e declínio da representação dos principais partidos de direita.

Em 1964, Eduardo Frei, do PDC, elegeu-se presidente com 55\% dos votos; desde o início do seu mandato, procurou governar acima dos partidos; consequentemente, o sistema partidário ficou cada vez mais reduzido a três blocos competitivos, que não se aliavam. Já em 1970, Salvador Allende foi eleito com apenas 36\% dos votos; no entanto, o sistema já se mostrava totalmente conflituoso e centrífugo, com ideologias extremadas, levando à quebra do regime democrático, em 1973.

Assim, desde meados dos anos trinta até o colapso da democracia, em 1973, o sistema partidário chileno teve um caráter multipartidário e estruturação ideológica, com forte divisão entre segmentos de direita, um de centro e outro de esquerda, evidenciando um sistema de partidos polarizado ao extremo, estruturado em torno do conflito Estado-lgreja e do conflito de classe (SCULLY;VALENZUELA, 1993).

Durante o regime autoritário de Augusto Pinochet, os partidos políticos foram banidos; já os partidos de direita entraram em recesso, enquanto os de esquerda foram reprimidos; por sua vez, o PDC tinha relacionamento privilegiado com a igreja, recebendo indulgência do regime. Em 1980, ainda durante a ditadura militar, foi promulgada a nova Constituição que ainda permanece vigente - representando a coroação de um processo histórico que envolveu a gradual expansão dos poderes presidenciais, caracterizada pelo domínio do Poder Executivo ${ }^{8}$ e por um sistema eleitoral designado a limitar a fracionalização do sistema

8 De acordo com a Constituição de 1980, o sistema político chileno é amplamente dominado pelo Poder Executivo. Mesmo que as reformas de 1989, 1991, 1994 e 2005 tenham limitado alguns poderes presidenciais, o chefe do Executivo do país continua sendo um dos mais poderosos da América Latina, controlando o processo legislativo, pois detém exclusividade de iniciativa em diversas áreas, controle do processo orçamentário e uma gama de urgências e opções de veto, tornando-o definidor da agenda política (ANINAT et al., 2004). 
T\&P Redemocratização e partidos políticos no Brasil e no Chile: incentivos institucionais, sistema partidário e processo decisório

partidário, fornecendo benefícios para os partidos de direita e limitando a representação congressual da maioria dos partidos políticos. Como reflexão jurídica da visão negativa do governo militar sobre a capacidade dos processos políticos democráticos, foi projetada para prevenir a emergência da polarização e da instabilidade; ademais, os partidos não poderiam monopolizar a representação, o que encorajou a presença de candidatos independentes.

Mas, mais importante para a presente análise, cabe destacar, assim como no caso brasileiro, a presença de dispositivos institucionais herdados do regime militar, os chamados "enclaves autoritários", que condicionaram o funcionamento da democracia. Dentre eles, pode-se citar a existência de senadores designados, as leis de quórum especial com necessidade de super maiorias e o sistema eleitoral binomial, o que fez que preservassem os interesses das elites políticas e econômicas do período militar?

Em primeiro lugar, após perder o plebiscito de 1988 e com o retorno da democracia, a presença de nove senadores designados (ou seja, 1/3 do Senado) continuou a distorcer o relacionamento entre os partidos no plano governamental. Isso porque, além dos 38 senadores eleitos, havia 9 designados pelo governo e 2 vitalícios (neste caso, os últimos presidentes possuíam cadeiras no Senado). De acordo com o art. 45 da Constitución Política de la República de Chile (CHILE, 1980), dos nove senadores institucionais, quatro deveriam ser escolhidos pelo Conselho de Segurança Nacional - controlado por Pinochet durante os anos noventa -, três pela Corte Suprema, um pelo Presidente e um pelo Procurador-Geral. Somente em 16 de agosto de 2005 o Congresso aboliu a previsão de senadores designados, de maneira que a Reforma Constitucional entrou em vigor em 2006, permitindo fossem eliminados os senadores designados e vitalícios.

Em segundo lugar, com o objetivo de preservar as mudanças introduzidas pelo regime militar, a Constituição de 1980 tornou mais dificultoso o processo de construção de maiorias em ambas as Casas para aprovar legislação, além da necessidade de supermaiorias, dependendo do assunto em questão, o que forçou a coalizão governista da Concertación a incluir partidos de oposição para obter a governabilidade ${ }^{10}$.

Por fim, em terceiro lugar, além da manutenção da força do Poder Executivo, uma das mais importantes facetas da transformação feita pelos militares na Constituição

9 Augusto Pinochet, por exemplo, continuou sendo o Comandante em Chefe do Exército durante oito anos depois de instaurada a democracia, o que pode ter restringido a autonomia decisória dos primeiros governos democráticos.

10 Procurava-se, assim, impedir o retorno das características da Constituição de 1925, que facilitava a aprovação de matérias legislativas sem amplo apoio congressual, tornando o sistema mais volátil (SCULLY, 1995, p. 112). 
de 1980 foi a reforma do sistema eleitoral parlamentar. Os militares entendiam que o sistema de representação proporcional agravava as divisões da sociedade, permitindo a ascensão de uma partidocracia, caracterizada pela polarização ideológica. Sendo assim, as reformas introduzidas pelos militares tinham dois objetivos (SIAVELIS, 2000). Em primeiro lugar, buscavam projetar um sistema que limitaria a fragmentação do sistema partidário, formando o bipartidarismo. E isso seria feito através do sistema eleitoral binomial. Já o segundo objetivo era elaborar uma fórmula eleitoral que garantisse a representação dos partidos de direita"1 . Sendo assim, os militares transformaram o sistema em distritos de dois membros. Para a Câmara dos Deputados, 60 novos distritos legislativos foram estabelecidos - em um total de 120 membros. Para o Senado, foram estabelecidos 19 distritos, cada um elegendo dois senadores, totalizando 38.

Enquanto o presidente chileno é eleito por sistema majoritário com dois turnos, a principal especificidade do sistema político é o sistema eleitoral binomial (CAREY, 2002; ANINAT et al., 2004; VÁSQUEZ, 2003). Para eleger representantes na Câmara dos Deputados, o Chile utiliza o sistema proporcional de lista aberta com dois representantes (magnitude 2) em cada um dos 60 distritos eleitorais, utilizando a fórmula D'Hondt para distribuição das cadeiras, sendo que cada partido (ou coalizão) apresenta dois nomes, mas o eleitor vota em apenas um candidato. Após a eleição, os votos dos dois candidatos de cada lista são somados, e o mais votado fica com a primeira cadeira. Em seguida, o número de votos do partido mais votado é dividido por dois. Se esse número for maior que a votação do segundo partido, o primeiro ficará com a segunda cadeira. Ou seja: o partido majoritário recebe as duas cadeiras do distrito somente se obter o dobro do número de votos conquistados pelo segundo colocado ${ }^{12}$.

Como efeito de tal sistema eleitoral, pode-se citar, em primeiro lugar, a redução do número relevante de atores advinda do forte incentivo dos partidos a formarem coalizões e o fortalecimento das lideranças nacionais dos partidos (ANINAT et al., 2004). Em segundo lugar, o modelo binomial faz com que as disputas políticas eleitorais

11 Segundo Siavelis (2000), os distritos foram desenhados de acordo com a preferência dos partidos de direita, que tinham maior apoio no meio rural do que no urbano.

12 Para um partido ou coalizão conseguir as duas cadeiras do distrito, ele precisa dobrar o voto do competidor mais próximo. Consequentemente, um partido precisa ganha somente $33,4 \%$ dos votos para obter uma cadeira, enquanto que precisa ganhar $66,7 \%$ dos votos para conseguir duas cadeiras. Dessa maneira, se a coalizão ou partido ganha $66,6 \%$ dos votos e seu mais próximo competidor recebe 33,4\%, cada um obtém uma cadeira, ou 50\% do total das cadeiras do distrito. De acordo com Nicolau (2004, p. 60), apesar de o Chile utilizar o sistema proporcional de lista aberta de distritos de dois representantes, muitos autores consideram que o sistema eleitoral do país é classificado como majoritário. 
T\&P Redemocratização e partidos políticos no Brasil e no Chile: incentivos institucionais, sistema partidário e processo decisório

ocorram principalmente no interior das coalizões - e não entre as mesmas. Como é muito difícil um partido conseguir ser eleito para as duas cadeiras de determinado distrito, a competição política ocorre primordialmente dentro das coalizões - definindo a primazia da competição intrapartidária em detrimento da disputa interpartidária (ALTMAN, 2004, p. 51; ALTMAN; LUNA, 2011). Então, o sistema eleitoral chileno favorece coalizões amplas, mas também aumenta a competição eleitoral entre partidos da mesma coalizão. Isso porque o sistema encoraja a identificação com o candidato - e não com o partido - o que faz parecer que a eleição real seja realizada dentro de cada lista da coalizão, e não entre governo e oposição (ANGELL, 2003, p. 103). Por fim, em terceiro lugar, a dificuldade de se obter 2/3 dos votos em cada um dos distritos, a facilidade em alcançar 1/3 dos votos somadas à regra que constrange a formação de coalizões apenas em nível nacional torna a formação de duas coalizões nacionais o resultado mais provável (ANINAT et al., 2004), onde um partido ou candidato pagaria um elevado custo caso decidisse deixar a coalizão a qual pertence.

Por conseguinte, a combinação de senadores designados, necessidade de supermaiorias e de sistema eleitoral binomial transformaram o sistema partidário chileno num dos mais estáveis da América Latina, como se verá a seguir. Isso permitiu a formação de governos multipartidários com coalizões disciplinadas e com posições políticas previsíveis, com enraizamento societário, com a negociação se tornando um pressuposto central para qualquer iniciativa do processo de tomada de decisão, encorajando um sistema político com alto nível de moderação entre as diferentes forças políticas (FLORES-MACÍAS, 2012, p.160).

\section{Relações Executivo/Legislativo no Brasil e no Chile: a formação de coalizões como condição necessária para o funcionamento do processo decisório}

Até meados dos anos noventa, havia uma postura extremamente crítica sobre o funcionamento do presidencialismo de coalizão na América do Sul, em especial no Brasil e no Chile, devido a fatores como a fragmentação do sistema partidário, a centralização do Poder Executivo e a indisciplina partidária, dentre outros. Tais variáveis ocasionariam um período de grande instabilidade democrática para o continente. 
Nas décadas anteriores, concomitantemente ao fortalecimento do Poder Executivo e enfraquecimento dos partidos políticos durante os governos militares, as críticas eram influenciadas pela perspectiva que dominou as análises sobre o presidencialismo, onde predominava a exaltação das virtudes do sistema parlamentarista, exacerbando o principal fator que deturpa o presidencialismo: a separação de poderes, que ocasionaria a falta de cooperação entre partidos políticos e Poder Executivo e, consequentemente, o surgimento de governos minoritários e de conflitos que levariam indubitavelmente ao colapso desse tipo de sistema (LINZ, 1978, 1994; VALENZUELA, 1998).

O ponto de partida é que a separação dos poderes, que define o presidencialismo, implica em uma relação de mútua independência entre o Executivo e o Legislativo, contrastando com a relação de mútua dependência que caracteriza os poderes em sistemas parlamentaristas. No presidencialismo, quando o Poder Executivo fosse considerado demasiado forte e centralizado (casos de Brasil e Chile), haveria maior utilização de seus poderes constitucionais para imposição de suas preferências, o que tornaria a Assembleia ineficaz (SHUGART; CAREY, 1992, p. 147). Por conseguinte, Legislativo e Executivo possuem interesses antagônicos, ocasionando pouco ou nenhum incentivo à formação de coalizões devido ao presidente não depender da cooperação dos legisladores e dos partidos políticos para se manter no cargo, preferindo não dividir o poder no processo político, encorajando, por conseguinte, a formação de governos minoritários e maximizando as chances de impasses legislativos. Caso formadas, as coalizões seriam caracterizadas pela fragilidade e indisciplina dos partidos, pois não haveria incentivos para a lealdade partidária, de maneira que as agremiações iriam esperar pelo eventual fracasso do governo para obter maiores chances de vitória nas eleições seguintes (STEPAN; SKACH, 1993, p. 17; LINZ, 1994, p. 41-42).

No Brasil e no Chile, após a transição democrática, muitos analistas procuraram exacerbar o tom pessimista em relação ao sistema presidencialista, evidenciando o problema da governabilidade a partir da força do Poder Executivo e da falta de incentivos para formação de uma base parlamentar viável e estável. Enquanto o Chile possuía partidos historicamente mais enraizados na sociedade e com maior institucionalização, disciplina e coesão, o sistema partidário brasileiro era considerado a partir do prisma da baixa institucionalização, cujos partidos seriam frágeis, com menos legitimidade e precária organização, além da presença marcante do clientelismo, da indisciplina e da 
T\&P Redemocratização e partidos políticos no Brasil e no Chile: incentivos institucionais, sistema partidário e processo decisório

falta de coesão interna (AMES, 2003). No Chile, enquanto o sistema eleitoral binomial favorecia o consenso entre os partidos, o sistema de representação proporcional brasileiro inviabilizaria a formação de governos majoritários, o que resultaria, na maioria dos casos, na falta de cooperação entre os poderes. Mas, tanto no Brasil quanto no Chile, o principal fator de crítica ao sistema provinha na ideia da força preponderante do Poder Executivo via poderes constitucionais, sejam eles reativos (que impedem mudanças no status quo) ou proativos (alterando o status quo), tornando-o o principal ator no processo legislativo, minando a atuação partidária.

Contudo, mesmo com a fragmentação partidária e o multipartidarismo, o sistema político de ambos os países possuem instituições corretivas que garantem a governabilidade, tais como os poderes presidenciais, a existência de lideranças partidárias e de um sistema partidário institucionalizado (FIGUEIREDO; LIMONGI, 1999; SIAVELIS, 2000). Nesse sentido, um Poder Executivo forte não necessariamente irá conduzir à paralisia legislativa, pois existem circunstâncias onde governos minoritários e coalizões são apoiados por maiorias legislativas em sistemas presidencialistas (LIMONGI, 2003; CHEIBUB, 2007). À medida que o Executivo domina a agenda legislativa e os líderes partidários são capazes de disciplinar suas bancadas, a governança pode emergir. Contudo, no presidencialismo, mesmo dominando a agenda legislativa, o Poder Executivo governa considerando a agenda da maioria, onde há a fusão das agendas dos dois ramos governamentais (FIGUEIREDO; LIMONGI, 2009). Não há uma agenda do Executivo isolada e independente do Legislativo. Existe, de outra maneira, uma agenda da maioria elaborada no interior da coalizão governista que responde aos interesses partidários. A formulação da agenda, então, é resultado de um processo de negociação e de barganha realizados para acomodação de interesses no interior do próprio partido ou dos partidos da coalizão, sendo que há conflitos e disputas entre seus formuladores (FIGUEIREDO; LIMONGI, 2009, p. 86-87). E, quando se considera um governo de coalizão, a agenda proposta deve expressar os interesses dos diferentes partidos governistas - corroborando para a análise das mais variadas políticas públicas a partir do embate entre oposição e situação. Nesse sentido, a agenda do Poder Executivo constitui-se por acordos que passam pela distribuição de pastas ministeriais entre diferentes partidos. A agenda, então, é realizada de acordo com a preferência da maioria, onde as ações do Executivo e do Legislativo se interpenetram e são consideradas. 
Por conseguinte, a cooperação existe, e é possibilitada por meio de acordos de coalizão, nos quais os partidos obtêm benefícios de cargos ministeriais em troca de apoio legislativo ao presidente. Uma coalizão partidária ocorre quando um conjunto de partidos políticos persegue objetivos comuns através de recursos, distribuindo os benefícios do cumprimento desses objetivos (STROM, 1990), sendo formada quando a política do partido do governo encontra-se distante das preferências dos outros partidos (CHEIBUB, 2007). Com isso, os partidos não pertencentes ao governo têm interesse em trocar ministérios por uma política mais próxima do seu ponto ideal. Ademais, para a coalizão ser formada, o Executivo deve considerar, em primeiro lugar, seu tamanho, ou seja, se convida poucos ou muitos partidos para fazer parte do governo; em segundo lugar, se as preferências ideológicas devem ser homogêneas ou heterogêneas; e, em terceiro lugar, a divisão de poder entre os membros da coalizão, considerando a porcentagem de ministérios distribuídos para cada partido pertencente ao governo (RAILE; PEREIRA; POWER, 2006).

Mas, então, como são formadas/compostas e mantidas/desenvolvidas as coalizões no Brasil e no Chile ao longo do atual período democrático? É de se esperar, por exemplo, a hipótese de que quanto mais heterogênea for a coalizão, mais conflito legislativo e partidário irá ocorrer. Por sua vez, quanto mais homogênea for a coalizão, menor será o número de conflitos. Portanto, o cerne da questão está relacionado com o fato de que as preferências ideológicas de formação e manutenção partidária de uma coalizão são fatores importantes para a maior participação do Poder Legislativo e dos partidos políticos nas políticas públicas em geral.

\section{Coalizões no Brasil: heterogeneidade e amplitude partidária}

Analisando o caso brasileiro no período pós-1988, cabe destacar que todos os governos brasileiros que obtiveram sucesso legislativo foram aqueles que governaram com coalizões amplas e heterogêneas (POWER, 2010), visando, acima de tudo, atingir objetivos legislativos do Executivo. Com isso, as coalizões legislativas não são apenas desproporcionais (com o número de membros maior do que o necessário para aprovar leis), mas também desconectadas (os partidos que compõem a aliança não são ideologicamente próximos uns dos outros), ou seja, com alta heterogeneidade ideológica, e com distribuição proporcional de cargos ministeriais. 
T\&P Redemocratização e partidos políticos no Brasil e no Chile: incentivos institucionais, sistema partidário e processo decisório

Grande parte dos presidentes brasileiros desde 1988 possuíram as mesmas ferramentas institucionais, mas enfrentaram diferentes condições de barganha e empregaram diversas táticas para conseguir o sucesso legislativo. Todos os ministérios formados desde a posse de Sarney, em 1985, até o final do segundo mandato de Lula, em 2010, combinaram multipartidarismo com maior ou menor grau de fragmentação e heterogeneidade ideológica.

O governo de José Sarney (1985-1990) iniciou seu trabalho com ministérios formados por Tancredo Neves, nos quais havia a repartição dos cargos entre os membros da Aliança Democrática - formada por PFL, PMDB, PTB e PDS. Aos poucos, Sarney tentou ganhar autonomia, sem romper com a base de sustentação partidária do governo, pois escolheu políticos de sua confiança provenientes do PFL e do PMDB, conquistando apoio de 64\% dos partidos da Câmara dos Deputados e de 62\% do Senado Federal. Entretanto, com a crise do Plano Cruzado, integrantes dos dois partidos retiraram o apoio ao presidente. E, em 1987, Aliança Democrática foi rompida, fazendo com que Sarney construísse maiorias parlamentares sem uma base sólida de sustentação. Sarney sempre buscou alcançar autonomia frente aos ministros, procurando realizar suas próprias escolhas e manter a governabilidade. No entanto, precisou dividir o poder para governar, pois não gozava de tanta legitimidade - foi eleito indiretamente - e o momento econômico era de extrema instabilidade.

Já o governo de Fernando Collor de Melo (1990-1992), cuja administração foi marcada pela eleição de um outsider do sistema partidário e pelo processo de impeachment realizado em 1992, efetivou de maneira errônea a distribuição de cargos ministeriais, procurando governar acima dos partidos e dos grupos de interesse. Isso porque o perfil ministerial foi definido pelo marketing político e pela imagem pública dos seus ocupantes - sem considerar o peso da representação política (ABRUCIO; LOUREIRO, 1998, p. 11). Sendo assim, no início de seu governo havia somente três partidos políticos (PFL, PMDB e PRN) na coalizão - que ocupavam 49\% das cadeiras da Câmara dos Deputados. Era, portanto, uma coalizão minoritária. Com a debandada do PMDB, Collor tentou governar sem o apoio dos partidos. No entanto, quando começou a enfrentar problemas e acusações de corrupção, buscou-se um novo perfil ministerial com a inclusão do PSDB, do PTB e do PL. Mas tal mudança não foi capaz de impedir o desgaste político e o impeachment. 
Após a destituição de Collor, Itamar Franco assumiu a Presidência da República até 1995, com comprometimento de apoio partidário. Franco privilegiou a construção de maiorias estáveis no Congresso Nacional, distribuindo ministérios aos partidos da base aliada. Com isso, sua base de sustentação girou em torno de 58\% na Câmara dos Deputados e 70\% no Senado Federal.

Com o exemplo mal-sucedido de Collor, a administração de Fernando Henrique Cardoso (1995-2002) compreendeu que governar sem uma coalizão estável seria arriscado. Com isso, houve a criação de amplas coalizões e, após seu primeiro mandato, conseguiu o apoio de quase 75\% da Câmara dos Deputados (PSDB, PFL, PTB, PMDB, PPS E PPB), recompensando proporcionalmente os partidos da coalizão com ministérios. Apesar de grande, a coalizão não sofria com diferenças ideológicas internas, além de possuir um perfil de centro-direita.

Já a partir de 2003 até o fim do seu primeiro mandato, em 2006, Luis Inácio Lula da Silva realizou 64 nomeações. Pela primeira vez, o PT assumia o principal cargo do Executivo, encontrando dificuldades com a distribuição de preferências ideológicas no Legislativo, pois a maioria das cadeiras da Câmara dos Deputados pertencia a partidos de centro e de direita. $O$ presidente, então, precisava atuar de maneira mais centrista, obtendo o apoio de setores da direita da distribuição ideológica - como foi o caso do PL (atual PR). E para acomodar as facções internas do PT, Lula aumentou o número de pastas ministeriais de 21 para 35. Portanto, em seu primeiro ano de governo, o Chefe do Executivo satisfez as facções internas do partido, pois distribuiu 20 pastas ao PT. Havia uma clara preocupação com a proporcionalidade dentro do partido do que entre partidos membros da coalizão governista (PEREIRA; POWER; RAILE, 2009, p. 221).

Já o segundo ministério de Lula, a partir de 2004, exibiu uma proporcionalidade mais baixa em função da entrada do PMDB, que recebeu apenas dois cargos ministeriais, diminuindo o índice de proporcionalidade da coalizão. Dessa maneira, a crise política que se abateu sobre o país a partir de junho de 2005 teve sua origem na formação do governo Lula, no início de 2003. Isso porque as decisões em relação à maneira de formar e manter sua base criaram terreno fértil para a crise que explodiu em 2005. O governo Lula não atendeu às expectativas dos outros partidos da coalizão - que receberam poucos cargos nos ministérios. Ademais, a grande maioria das políticas distributivistas foi destinada aos partidos de fora da coalizão, pois o governo tinha interesse em 
T\&P Redemocratização e partidos políticos no Brasil e no Chile: incentivos institucionais, sistema partidário e processo decisório

aprovar reformas constitucionais (PEREIRA; POWER; RAILE, 2009). Segundo Amorim Neto (2007), a principal razão para o surgimento da crise política reside na fragmentação do governo Lula, com ministérios muito amplos, altamente partidarizados e heterogêneos ideologicamente, e desequilibrados em termos da proporcionalidade entre o peso legislativo dos partidos e sua participação ministerial. O PT, por exemplo, possuía 29\% da base parlamentar, mas controlava 60\% dos ministérios. Já o PMDB representava 25\% da maioria legislativa, mas só estava à frente de dois ministérios (6\% do total). Ou seja: apesar de Lula querer formar um governo de coalizão, não houve partilha efetiva do poder. Tal fato gerou uma insatisfação crescente, principalmente entre PTB e PL (definidos como partidos de direita). Com isso, os desequilíbrios internos desencadearam uma crise política que chegou ao seu ápice em maio de 2005.

Por fim, durante o segundo mandato, Lula continuou a formar gabinetes ministeriais com grande diversidade partidária, o que se refletiu no aumento da bancada governista da Câmara dos Deputados (que chegou ao patamar de 70\% de representação entre 2008 e 2010) e a manutenção dos índices encontrados no Senado Federal (em torno de 58\%) - em relação aos quatro anos anteriores.

Portanto, grande parte dos presidentes brasileiros do período pós-1988 tiveram sucesso em aprovar sua agenda legislativa, formaram coalizões para governar e obtiveram apoio confiável dos partidos da base governista. Esse resultado provém da maneira como o Congresso brasileiro, altamente centralizado, é organizado e também da articulação dos partidos políticos e dos líderes partidários, que são peças imprescindíveis para a manutenção do equilíbrio entre os poderes. A combinação entre sistema partidário razoavelmente estabilizado, presidentes fortes e processo decisório centralizado garante que o presidencialismo brasileiro apresente os padrões de eficácia governamental observados.

\section{As coalizões ideológicas do Chile}

A transição democrática, de caráter pactuado, fez com que os militares conservassem poder para estabelecer as características do novo regime, além de condicionar a reestruturação do sistema de partidos. Com isso, houve o surgimento de novos partidos e o desaparecimento de outros, além da diminuição da distância ideológica entre eles, modificando a estrutura de alianças e os eixos de competição partidária (LUNA, 2006). 
Mas mesmo com as mudanças efetuadas, os partidos políticos do atual período democrático possuem raízes que podem ser visualizadas tanto no período pré-regime militar como durante a ditadura de Augusto Pinochet.

A polarização do sistema partidário diminuiu, com moderação das posturas dos partidos de esquerda - especialmente o Partido Socialista - desmobilizando suas bases de apoio. Assim, o o radicalismo que caracterizara os partidos políticos da América Latina nos anos 1960 e 1970 foi substituído pelo compromisso com a democracia. E, no Chile, não foram apenas os partidos que se transformaram. O sistema partidário, como um todo, foi significativamente sujeito a modificações. Segundo Siavelis (2000), as duas transformações mais importantes foram a renovação programática dos partidos relevantes e a diminuição do fator ideológico.

Em primeiro lugar, transformações domésticas, como o fortalecimento de instituições políticas, e internacionais, como o fim da Guerra Fria, juntamente com a experiência autoritária, encorajaram o processo de renovação ideológica no Chile, fazendo com que nenhum partido grande prefira outro tipo de sistema político que a democracia. Os partidos de esquerda, como o PS (Partido Socialista) e o PPD (Partido por la Democracia), assumiram papeis ativos nos governos. No contexto da transição à democracia, o PS abandonou retórica marxista-leninista e a agenda de socialização dos meios de produção, adotou a estratégia eleitoral e a democracia liberal, e experimentou um processo de profunda renovação ideológica, de cunho moderado ${ }^{13}$, valorizando o consenso e o modelo neoliberal de mercado, passando a a formar coalizões amplas com o centro, e abandonando a histórica coalizão com o Partido Comunista ${ }^{14}$ (ROBERTS, 2011, p. 329). Já o outro partido de centro-esquerda relevante, o PPD, definido como um partido catchall15, também se caracterizou como uma alternativa moderada, mas com tendência mais centrista do que o PS, competindo para concorrer com os votos do eleitor mediano

13 A derrota do governo de Salvador Allende, a repressão durante a ditadura, os anos de exílio e o processo de transição à democracia configuraram um cenário que conduziram as elites política do partido a optar pela estratégia de moderação (ROBERTS, 1998). Contudo, a estratégia de moderação resultou de processo interno conflituoso, gerando diversas dissidências e a formação de duas correntes - o PS-Almeyda e o PS-Altamirano.

140 Partido Comunista Chileno se incorporou à ordem democrática, mas com menor força, possuindo participação escassa no debate politico e carecendo de representação congressual durante o período analisado como consequência do sistema eleitoral binomial, que impossibilitou sua representação parlamentar. Somente em 2009, graças a um pacto com a Concertación, o partido obteve representação parlamentar (GARRETÓN, 2008, p. 88; GAMBOA; LOPEZ; BAEZA, 2003).

15 De acordo com a definição clássica de Kirchheimer (1966, p. 184), o partido catch-all evidencia a procura de apoio para sucesso eleitoral imediato e transforma a ideia de que um partido deve representar setores pré-definidos da sociedade; vencer eleições é primordial, de modo que o apelo eleitoral não dever ser restrito a um tipo de grupo ou classe, mas sim, à totalidade e à heterogeneidade da população. 
T\&P Redemocratização e partidos políticos no Brasil e no Chile: incentivos institucionais, sistema partidário e processo decisório

tradicionalmente captado pelo PDC (HUNEEUS; BERRÍOS, 2005); ademais, se configurou como um partido de notáveis (ROBERTS, 1998). Com o aumento do pragmatismo dos partidos de esquerda e de centro-esquerda, houve maior cooperação com os partidos de centro, sendo que o PDC se tornou a principal organização partidária, experimentando a moderação ideológica em relação ao posicionamento que teve durante os anos sessenta, quando impulsionou uma ambiciosa agenda de reformas denominada de"Revolución en libertad". Portanto, durante o período pós-ditadura, os partidos integrantes da Concertación moderaram seus postulados programáticos e seus programas eleitorais, se organizaram como partidos eleitorais e profissionais ${ }^{16}$ (PANEBIANCO, 1990), optando por diminuir o conflito e a mobilização social e aumentar, assim, suas bases eleitorais entre os setores sociais médios da população, paralelamente ao desenvolvimento de uma estratégia de pactos entre as elites políticas (ROBERTS, 1998, p. 116; ALTMAN, 2004).

O consenso e a moderação prevalecerem, sem desconsiderar, contudo, as divergências internas da própria Concertación. Em 1998, um grupo de ministros de governo publicaram o documento La fuerza de nuestras ideas, assinalando os êxitos obtidos pelos governos da coalizão, atribuindo os problemas existentes no país ao processo de modernização. Um mês depois, outros membros do governo, descontentes com o desempenho e com a aliança de centro-esquerda, publicaram o documento La giente tiene razón, que criticava o caráter incompleto da democracia, a persistência das desigualdades estruturais e a desmobilização da sociedade civil (GARRETÓN, 2012). Portanto, a moderação é característica dos partidos de centro e de centro-esquerda, mas ainda há espaço para o conflito de ideias dentro da própria coalizão.

Já os partidos de direita, a RN (Renovación Nacional) e a UDI (Unión Democrática Independiente), nasceram a partir do Partido Nacional e do movimento Gremialista, e abandonaram a ideia de que a representação política poderia ser organizada de maneira não democrática, e estabeleceram um forte vínculo com grupos de interesse econômicos, especialmente com o empresariado. Contudo, a RN manteve grupos da direita tradicional vinculados ao regime militar ao mesmo tempo em que surgiram críticos desse regime, evidenciando um perfil mais liberal (GAMBOA; LOPEZ; BAEZA, 2013). Já a UDI surgiu a partir do Movimiento Gremial, fundado em 1965, e passou a se constituir

16 Os partidos eleitorais e profissionais se caracterizam pela centralidade dos politicos profissionais, pela orientação eleitoral e pelo estabelecimento de fracos vínculos verticais com os membros do partido. 
como o principal apoio do regime militar, mas passou a enfatizar a necessidade de abandonar atitudes classistas, comprometendo-se com a manutenção da democracia. Ambos os partidos são portadores de uma ideologia de direita, de defesa do Estado mínimo e do funcionamento da economia de mercado, mas com diferenças. Enquanto a UDI tem um perfil liberal no plano econômico e conservador na questão dos valores, com defesa do legado autoritário, a RN também possui um perfil econômico liberal, mas crítico em relação ao legado autoritário.

Em segundo lugar, no Chile contemporâneo, as legendas não são mais caracterizadas pela polarização dos anos 1970, mas sim pelo pluralismo moderado, o que fez aumentar o grau de interação, de cooperação interpartidária e de formação de coalizões. Houve moderação do conteúdo ideológico, mas o pluralismo continuou, com governos de coalizões. Assim, os partidos políticos convergiriam para o eleitor mediano, apresentando baixo nível de polarização (GUZMÁN, 1993; VÁSQUEZ, 2003).

Todavia, diversas análises empíricas observaram que o sistema binomial pode encorajar a competição centrífuga, com existência de polarização ideológica entre os partidos políticos chilenos, de maneira que a formação de coalizões incentiva posições ideológicas semelhantes no plano intra-coalizão e divergentes no aspecto intercoalizões (DOW, 1998). Há um alto grau de coesão e de disciplina dentro das coalizões, prevalecendo a homogeneidade interna na Concertación, e a forte oposição dos partidos da Alianza (ALEMÁN; SAIEGH, 2006) - embora a RN tenha maior disposição para negociar com o governo, enquanto que a UDI tem uma postura sistematicamente de oposição (MAUREIRA, 2007). Por fim, há baixa incidência de legisladores localizados no centro do espectro ideológico, evidenciando a polarização político-partidária na Câmara dos Deputados e no Senado Federal (FELIÚ, 2008).

Assim, de início, as alianças partidárias passaram a refletir a divisão entre os partidos que apoiaram e os que se opuseram ao regime militar - e não mais em razão de clivagens ideológicas. Com sua reestruturação, o sistema partidário chileno passou a organizar-se em torno do eixo democracia-autoritarismo. Atualmente, pode-se destacar que o fator ideológico é uma variável central, o que delimita a configuração político-partidária e as preferências dos congressistas em políticas públicas.

No final da década de 1980, os partidos se uniram para se opor a Pinochet. Dentre eles, o PS e o PDC, que objetivavam a volta à democracia; ademais, houve o ressurgimento 
T\&P Redemocratização e partidos políticos no Brasil e no Chile: incentivos institucionais, sistema partidário e processo decisório

de partidos de esquerda, como o PPD (Partido para a Democracia), com tendência moderada. Com o plebiscito de 1988, no qual a população deveria decidir se Pinochet continuava no poder, 13 partidos oposicionistas de centro e de esquerda formaram a Concertación dos partidos para o NÃO - dentre eles, o centrista PDC e os principais partidos de esquerda, o PS, o PPD e o PRSD, de menor apelo eleitoral; por sua vez, a RN e a UDI (ambas de direita) apoiaram o ditador. Houve vitória do NÃO, e Pinochet foi rejeitado com $54 \%$ dos votos.

Com a inauguração do novo regime democrático, o partido eleito para a presidência necessita contar com o apoio das coalizões. Isso porque é praticamente improvável a eleição de um presidente apenas com o respaldo de seu próprio partido e que este detenha a maioria dos assentos no Congresso (NOLTE, 2003). Assim, assim como no caso brasileiro, é necessária a formação de coalizões para garantir a estabilidade e a governabilidade do sistema político ${ }^{17}$. E ao observar a formação das coalizões no Chile, pode-se notar a coalizão de centro-esquerda denominada Concertación, que governou o Chile de 1990 a 2010, sendo formada por PS (Partido Socialista de Chile), PPD (Partido por la Democracia), PRSD (Partido Radical Social Demócrata) ${ }^{18}$ e PDC (Partido Demócrata Cristiano), de tradição centrista. Já o Partido Comunista não se integrou ao pacto, diferentemente dos anos setenta, quando formou a aliança partidária governamental; preferiu, juntamente com o PH (Partido Humanista), formar o pacto Juntos Podemos, de menor expressão.

Já a coalizão de direita, que foi oposição até 2010, é denominada, atualmente, como Coalición por el Cambio'19, e é composta por UDI (Unión Demócrata Independiente), RN (Renovación Nacional), CH1 (ChilePrimero) e MHC (Movimiento Humanista Cristiano). Tanto a RN, formada a partir do Partido Nacional, quanto a UDI (que contava com diversos

17 Para o caso chileno, é possível enumerar alguns fatores que favorecem a formação de coalizões, tais como: o sistema eleitoral de maioria absoluta, que gera forte incentivo para a formação de coligações que se tornarão coalizões governamentais; a existência de um sistema de compensações através dos cargos no governo; as coalizões não correspondem somente a cálculos eleitorais, mas também se baseiam em um programa de governo comum e com consenso; existe uma coordenação de trabalho entre o Congresso e os parlamentares dos diferentes partidos que formam a coalizão, o que é refletido na composição das mesas parlamentares, nas presidências e nos integrantes das comissões, e nas votações das bancas que são membros da aliança; os cargos ministeriais se dividem entre os partidos membros da coalizão levando em consideração seu apoio eleitoral (NOLTE, 2003).

18 Nas eleições legislativas de 1997, o Partido Radical (PR) se fundiu ao Partido Social Demócrata (PSD), criando o Partido Radical Social Demócrata (PRSD).

19 Nas eleições de 1989, a Coalición por el Cambio chamava-se Democracia y Progreso. Em 1993, denominava-se Unión por el Progreso. Já em 1997, mudou o nome para Unión por Chile. Nas eleições de 2005, adotou o nome de Alianza por Chile, que perdurou até a eleição de Piñera, em 2009. 
líderes políticos que haviam ocupado posições políticas privilegiadas durante o governo militar), principais partidos da coalizão, surgiram durante o período militar e apoiaram sua continuidade no plebiscito de 1988.

Como visto anteriormente, a estabilidade das alianças de centro-esquerda e de direita deriva dos incentivos gerados pelo sistema eleitoral binomial, que foi configurado pelo governo autoritário como forma de sobre-representação do bloco de direita e manter baixo controle sobre os níveis de fragmentação partidária (SCULLY, 1995).

O primeiro presidente eleito pelo atual sistema democrático chileno foi Patrício Aylwin, do PDC. Foi eleito, em 1989, com 55,1\% dos votos e contou com o apoio legislativo de PS (15\%), PPD (13,3\%), PDC (31,6\%) e PRSD (5\%), totalizando 56,6\% das cadeiras do Congresso Nacional. No governo Aylwin, todos os partidos políticos com representação na Câmara dos Deputados foram agraciados com ministérios. O PDC foi o partido com o maior percentual de ministérios: 13, ou 52\%. O PS, segundo partido na Câmara dos Deputados (15\%), arregimentou 24\% (6, no total) das pastas ministeriais (PASQUARELLI, 2011).

Já em 1993, Eduardo Frei, também do PDC, foi eleito com 58,0\% do total de votos, e ocupou o cargo até o ano de 2000. Durante o período, sua base de apoio congressual foi de aproximadamente 58,2\%, sendo sustentado por PS (13,3\%), PPD (12,5\%), PDC (30,8\%) e PR $(1,6 \%)^{20}$. Tanto Aylwin quanto Frei construíram maiorias através da negociação e do compromisso a fim de introduzir mudanças e reformas de maneira gradual. Estas dinâmicas estabeleceram a etapa da democracia consensual - o princípio definidor dos dois primeiros governos democráticos (SIAVELIS, 2000, p. 223)21.

Nas eleições de 1999, Ricardo Lagos, do PS, obteve vitória no primeiro turno e no segundo turno, com 47,95\% e 51,3\% dos votos, respectivamente. Até 2005, governou com base de apoio partidário menor do que aquela verificada nas administrações Aylwin e Frei, pois totalizou 51,8\% das cadeiras do Congresso Nacional, no qual o PDC manteve-se como o partido aliado com maior representatividade (20\%), seguido por PPD (17,5\%), PS (9,2\%) e PRSD (5\%). Já a UDI, principal partido opositor, aumentou drasticamente seu percentual de representação, passando a possuir $25 \%$ de assentos.

20 Fonte: Tribunal Calificador de Elecciones de Chile e Observatório de Política Sul-Americana.

21 Porém, segundo Siavelis (2000), as raízes do sucesso da administração de Aylwin e de Frei não são resultado da engenharia institucional feita pelos militares, mas sim do contexto político, social e partidário criado pelo processo de democratização. 
T\&P Redemocratização e partidos políticos no Brasil e no Chile: incentivos institucionais, sistema partidário e processo decisório

Nas administrações Frei e Lagos, a dinâmica manteve-se praticamente a mesma: o PDC, maior partido na Câmara, obteve metade dos cargos ministeriais (25). E o PPD, com o aumento da representatividade, passou a receber maior número de ministérios (16\% e 21\% do total nos governos Frei e Lagos, respectivamente), assemelhando-se ao total de ministros do PS.

Já em 2006, Michelle Bachelet, também do PS, elegeu-se com 53\% dos votos no segundo turno - após receber 46\% de apoio nas urnas no primeiro turno. Assim como Lagos, sua base governista congressual também foi relativamente baixa $(51,8 \%)$, sendo novamente o PDC o principal partido da base aliada (20,8\%), seguido por PPD (15,6\%), PS (9,8\%), PRSD (3,5\%) e por partidos independentes (2\%). Contudo, durante o período de 2000 a 2009, apesar do menor índice de representatividade no Congresso Nacional e do crescimento da UDI no campo da oposição, tanto Bachelet quanto seu antecessor, Ricardo Lagos, conseguiram implementar algumas reformas e estipularam novas formas de atuação política, principalmente em questões sociais e de política externa. Algumas mudanças ocorreram após a eleição de Bachelet, em 2006. Na Câmara dos Deputados, a UDI e a RN (ambos pertencentes à coalizão Alianza por Chile) tornaram-se os dois maiores partidos. Na base governista, quem obteve o maior índice de representação foi o PPD (15\%, ou 13 no total), mas quem continuou com a maioria dos cargos ministeriais foi o PDC, com 16 (36\%). Portanto, pode-se observar que, durante 1990 a 2010 - período no qual a coalizão Concertación governou - houve grande semelhança de representação na Câmara dos Deputados e nos ministérios.

Por fim, Sebastian Piñera, da RN (pertencente à Coalición por el Cambio), foi eleito em 2010 com 51,6\% dos votos do segundo turno. Contou com 46\% de base de apoio parlamentar.

Em suma, durante os primeiros pleitos, a Concertación manteve-se como a principal coalizão, obtendo a maioria das cadeiras no Congresso. Contudo, a partir de 1999, começou a perder apoio eleitoral, sendo que o bloco de centro-direita foi fortalecendo sua base eleitoral, se tornando um ator com forte capacidade de veto congressual, até transformar-se no partido governista nas eleições de 2009. O poder de veto se tornou ainda mais importante em função das maiorias especiais que se requerem para apoiar ou reformar um conjunto de normas, cujo trâmite os governos da Concertación tiveram que negociar com a oposição conservadora (ANINAT et al., 2006, p. 24). Por conseguinte, 
o Partido Socialista, durante os governos de Lagos e de Bachelet, teve que interagir com os diversos partidos da coalizão governista e mesmo com os partidos de direita (RN e UDI), mantendo uma democracia consensual, com abertura de espaço para o diálogo com a oposição e cooperação com o Congresso.

\section{Conclusão}

Com o final dos regimes autoritários e o retorno à democracia, os partidos políticos do Brasil e do Chile se moldaram conforme as características do período anterior, prevalecendo fatores tais como a centralização do processo decisório nas mãos do Poder Executivo, a manutenção de sistemas eleitorais que prejudicassem partidos de esquerda, e a formação de coalizões para lidar com o problema de governos minoritários. Contudo, apesar de diversas semelhanças contextuais, os dois países se diferenciam em algumas características.

No Chile, um sistema partidário fortemente institucionalizado²2 forneceu incentivos para a moderação com dinâmica centrípeta e para a construção de coalizões governamentais estáveis e com maior homogeneidade, que buscaram promover acordos por meio da deliberação e da construção do consenso, concedendo aos partidos a oportunidade para moldar, de acordo com suas preferências, os resultados nas mais variadas políticas públicas. Então, o processo de tomada de decisão no presidencialismo chileno deve ser entendido a partir de um sistema de incentivos para a negociação intrapartidária, interpartidária e inter-coalizão, no qual o Poder Executivo necessita do apoio legislativo para governar. Mesmo que possuam fortes poderes, os presidentes chilenos procuram formar maiorias para aprovação de seus projetos, o que resulta em um processo de tomada de decisão caracterizado pelo consenso, e não pelo extremismo ou pelo conflito. Desde a volta da democracia, na década de noventa, a Concertación foi forçada a negociar com ao menos um dos partidos de direita para aprovar legislação, obtendo o consentimento de uma oposição previsível e estável. Consequentemente, a escolha pela continuidade

22 Tal institucionalização foi possível devido a quatro características centrais (FLORES-MACÍAS, 2012, p. 152): apesar do regime autoritário ter interrompido a atuação de diversos partidos políticos, houve a continuidade das principais legendas partidárias, sendo que a identificação e a lealdade partidária permaneceram ao longo dos anos; presença de lideranças partidárias com ampla trajetória de negociação; forte conexão entre partidos políticoe e sociedade civil - apesar do declínio nos anos recentes; e, por fim, a correspondência entre as plataformas dos candidatos e as políticas implementadas quando no governo. 
T\&P Redemocratização e partidos políticos no Brasil e no Chile: incentivos institucionais, sistema partidário e processo decisório

e manutenção de políticas propostas ocorre devido a um ambiente político no qual os presidentes se pautam por atitudes moderadas e visando a construção do consenso, e onde há o compromisso partidário em favor do Poder Executivo.

No Brasil, por sua vez, o sistema partidário que emergiu sob a égide dos militares era considerado como imprevisível, com alianças instáveis e posições ideológicas extremas, baixa disciplina partidária e fracos laços com a sociedade. Ademais, enquanto o surgimento os partidos políticos chilenos pós-Pinochet podem ser rastreados ao se observar o período pré-colapso da democracia, a ditadura militar do Brasil rompeu com o sistema partidário anterior, criando artificialmente dois partidos políticos (MDB e Arena) e inserindo regras eleitorais que permitiram o surgimento de várias agremiações partidárias em meados da década de oitenta, ocasionando a fragmentação do sistema. Contudo, o sistema partidário brasileiro se tornou cada vez mais institucionalizado e previsível, com partidos com altos níveis de disciplina, permitindo que os presidentes garantissem maiorias multipartidárias e que os partidos políticos representados no Congresso moldassem as políticas públicas. Mas a presença de coalizões mais amplas e heterogêneas e não tão estáveis quanto as chilenas faz com que as posições políticas não sejam tão previsíveis, aumentando a presença do conflito entre Poder Executivo e partidos políticos governistas e oposicionistas e ocasionando a diferenciação da atuação dos governos, de acordo com a lógica de formação das coalizões.

\section{Referências}

ABRUCIO, F. L.; LOUREIRO, M. R.. Burocracia na Nova Ordem Democrática Brasileira: o provimento de cargos no alto escalão do Governo Federal (Governos Sarney, Collor, Itamar Franco e FHC). São Paulo: EAESP/FGV/NPP - Núcleo de Pesquisas e Publicações, 1998.

ALTMAN, D. Redibujando el mapa electoral chileno: incidencia de factores socioeconómicos y género em las urnas. Revista de Ciencia Política, v. 24, n. 2, p. 49-66, 2004.

ALTMAN, D.; LUNA, J. Uprooted but Stable: Chilean Parties and the Concept of Party System Institutionalization. Latin American Politics And Society. 2011. p. 1-28.

AMES, B. Os entraves da democracia no Brasil. Rio de Janeiro: Editora FGV, 2003.

AMORIM NETO, O. O Poder Executivo, centro de gravidade do sistema político brasileiro. In: AVELAR, L.; CINTRA, A. O. (Ed.). Sistema político brasileiro: uma introdução. 2. ed. Rio de Janeiro: Fundação Konrad Adenauer, 2007. p.131-141. 
ANINAT, C. et al. Political institutions, policy making process, and policy outcomes in Chile. 2004. Manuscript.

BRAGA, M. S. S. O processo partidário-eleitoral brasileiro: padrões de competição política (19822002). São Paulo: Humanitas/FAPESP; 2006.

BRAGA, M. S. S. Eleições e democracia no Brasil: a caminho de partidos e sistema partidário institucionalizados. Revista Brasileira de Ciência Política, n. 4, p. 169-186, 2010.

CARDOSO, F. H. Desenvolvimento associado-dependente e a teoria democrática. In: STEPAN, A. (Org.). Democratizando o Brasil. Rio de Janeiro: Paz e Terra, 1988. p.483-482

CAREY, J. M. Parties, Coalitions, and the Chilean Congress in the 1990s. In: MORGENSTERN, S.; NACIF, B. (Org.). Legislative politics in Latin America. Cambridge: Cambridge University Press, 2002. p.222-253.

CARVALHO, J. M. Cidadania no Brasil: o longo caminho. Rio de Janeiro: Civilização Brasileira, 2008.

CHEIBUB, J. A. Presidentialism, parlamentarism, and democracy. Cambridge: Cambridge University Press, 2007.

CHILE. Constitución (1980). Constitución Política de la República de Chile. Santiago, 21 oct. 1980.

DOW, J. A Spatial analysis of candidates in dual member Districts: the 1989 Chilean Senatorial Elections, Public Choice, v. 97, p. 119-142, 1998.

FELIÚ, P. Votações Nominais, Espectro Ideológico Político-Partidário e Política Externa: o caso chileno (1994-2006). 2008. 97 f. Dissertação (Mestrado em Ciência Política)-Departamento de Ciência Política, Universidade de São Paulo, São Paulo, 2008.

FIGUEIREDO, A.; LIMONGI, F. Executivo e Legislativo na Nova Ordem Constitucional. Rio de Janeiro: Editora FGV, 1999.

FIGUEIREDO, A.; LIMONGI, F. Poder de agenda e políticas substantivas. In: INÁCIO, M.; RENNÓ, L. (Org.). Legislativo Brasileiro em Perspectiva Comparada. Belo Horizonte: Editora UFMG. 2009. p. 77-104.

FLORES-MACÍAS, G. After Neoliberalism? The Left and Economic Reform in Latin America. Oxford: Oxford University Press, 2012.

GARRETÓN, M. Matriz sociopolítica y desarrollo socioeconómico en Chile. Manchester: School of Environment \& Development, University of Manchester, 2007. Discussion Paper Series, 15. GARRETÓN, M. Neoliberalismo corregido y progresismo limitado: los gobiernos de la Concertación en Chile 1990-2010, Buenos Aires: Editorial ARCIS CLACSOPROSPAL, 2012.

GUZMÁN, E. Reflexiones sobre el sistema binomial. Estudios Publicos, n. 51, p. 303-325, 1993.

KINZO, M. D. G. O quadro partidário e a Constituinte. In: LAMOUNIER, B. (Org.). De Geisel a Collor: o balanço da transição. São Paulo: Sumaré, 1990.

KINZO, M. D. G. A Democratização Brasileira: um balanço do processo político desde a transição. São Paulo em Perspectiva, v. 15, n. 4, p. 3-12, 2001. 
T\&P Redemocratização e partidos políticos no Brasil e no Chile: incentivos institucionais, sistema partidário e processo decisório

KIRCHHEIMER, O. The Transformation of the Western European Party Systems. In: PALOMBARA, J. L.; WEINER, M. (Ed.). Political parties and political development. Princeton: Princeton University Press, 1966. p.177-200.

LIMONGI, F. Formas de Governo, Leis Partidárias e Processo Decisório. BIB, n. 55, p. 7-40, 2003.

LINZ, J. The break down of democratic regimes: crisis, breakdown, and reequilibration. Baltimore: Johns Hopkins University Press, 1978.

LINZ, J. Presidential or Parliamentary Democracy: Does It Make a Difference? In: LINZ, J.; VALENZUELA, A. (Ed.). The Failure of Presidential Democracy: The Case of Latin America. Baltimore: Johns Hopkins University Press, 1994. p. 3-90.

LUNA, J. P. Chile and Uruguay: the evolution of programmatic and non programmatic party-voter link ages in two institutionalized party systems. 2006. 555 páginas (Doctoral Dissertation Political Science)-University of North Carolina at Chapel Hill, Chapel Hill, 2006.

MAUREIRA, S. T. Conducta Legislativa ante las Iniciativas del Ejecutivo: Unidad de los Bloques Políticos en Chile. Revista de Ciencia Política, v. 27, n. 1, p. 23-41, 2007.

NICOLAU, J. Sistemas eleitorais. Rio de Janeiro: FGV, 2004.

NOLTE, D. El Congreso Chileno y su Aporte a la Consolidación Democrática en Perspectiva Comparada. Revista de Ciencia Política, v. 23, n. 2, p. 43-67, 2003.

PASQuARELLI, B. A atuação do Poder Executivo e dos Partidos Políticos no Presidencialismo Chileno (1990-2010): Sistema Eleitoral, Apoio Legislativo, Negociações e Distribuição de Cargos. Leviathan - Cadernos de Pesquisa Política, v. 3, p. 1-28, 2011.

PEREIRA, C.; POWER, T; RAILE, E. Presidencialismo de coalizão e recompensas paralelas: explicando o escândalo do Mensalão. In: INÁCIO, M.; RENNÓ, L. (Org.). Legislativo Brasileiro em Perspectiva Comparada. Belo Horizonte: Editora UFMG, 2009. p. 77-104.

POWER, T. Optimism, Pessimism, and Coalitional Presidentialism: debating the Institutional Design of Brazilian Democracy. Bulletin of Latin American Research, v. 29, n. 1, p. 18-33, 2010.

RAILE, E.; PEREIRA, C.; POWER, T. The Executive Toolbox: Building Legislative Support in a Multiparty Presidential Regime. Political Research Quarterly, v. 10, n. 20, p. 1-12, 2006.

ROBERTS, K. M. Deepening democracy? The Modern Left and Social Movements in Chile and Peru. Stanford: Stanford University Press, 1998.

ROBERTS, K. M. Chile. The left after Neoliberalism. In: LEVITSKY, S.; ROBERTS, K. M. (Ed.). The Resurgence of the Latin American Left. Baltimore: The Johns Hopkins University Press, 2011. p. 325-348.

SCULLY, T. R.; VALENZUELA, J. S. De la democracia a La democracia. Continuidad y variaciones em las preferencias del electorado y en el sistema de partidos en Chile. Estudios Públicos, v. 51, p. 195-228, 1993. 
SCULLY, T. Reconstituting Party Politics in Chile. In: MAINWARING, S.; SCULLY, T. R. (Ed.). Building democratic institutions - party systems in Latin America. Stanford: Stanford University Press, 1995. p. 100-137.

SHUGART, M. S.; CAREY, J. M. Presidents and Assemblies: Constitutional Design and Electoral Dynamics. Cambridge, Cambridge University Press, 1992.

SIAVELIS, P. The President and the Congress in Postauthoritarian Chile: Institutional Constraints to Democratic Consolidation. Pennsylvania: The Pennsylvania State University Press, 2000.

SOUZA, M. C. C. A Nova República Brasileira: sob a Espada de Dâmocles. In: STEPAN, A. (Org.). Democratizando o Brasil. Rio de Janeiro: Paz e Terra, 1988.

SOUZA, M. C. C. Estado e Partidos Políticos no Brasil (1930 a 1964). São Paulo: Alfa-Omega, 1990.

STEPAN, A.; SKACH, C. Constitutional frameworks and democratic consolidation: parliamentarism versus presidentialism. World Politics, v. 46, p. 1-22, 1993.

VALENZUELA, A. The Crisis of Presidentialism in Latin America. In: autor(es). In Mainwaring, Scott and Valenzuela, Arturo. Politics, Society, and Democracy: Latin America. Boulder, CO: Westview, 1998. p. 121-139.

VÁSQUEZ, D. El sistema electoral binomial y las elecciones parlamentarias 1989-2005. Santiago: Biblioteca Del Congreso Nacional de Chile, 2003. (Serie estúdios, n. 1).

Recebido: 5 out., 2016 Aceito: 23 dez., 2016 